\title{
ARNOLD-CHIARI MALFORMATION PRESENTING WITH ATAXIA- A CASE REPORT
}

\author{
Dilip Pandurang Patil ${ }^{1}$
}

${ }^{1}$ Assistant Professor, Department of Medicine, Krishna Institute of Medical Sciences, Deemed To Be University, Karad, Maharashtra, India.

HOW TO CITE THIS ARTICLE: Patil DP. Arnold-Chiari malformation presenting with ataxia- a case report. J. Evolution Med. Dent. Sci. 2018;7(25):2969-2971, DOI: 10.14260/jemds/2018/669

\section{PRESENTATION OF CASE}

A 40 years old female, housewife by occupation presented with difficulty in walking, loss of balance while standing since last 15 days. In history, she told that she used to experience little loss of balance for last 3 months, but from last 15 days she is not able to walk without support. There was no headache, visual disturbance, difficulty in speaking or swallowing. There is no history of trauma to head. She is not hypertensive or diabetic. This complaint is not preceded by febrile illness. There was no bowel or bladder disturbance. She does not have habits like tobacco. There is no significant past history suggestive of major illness.

\section{CLINICAL DIAGNOSIS}

On physical examination, she was averagely built and nourished. Vitals were normal.

\section{Neurological Examination}

- Patient was conscious, oriented.

- Speech was normal with no dysarthria (Cerebellar or staccato speech).

- Other higher functions including memory was normal.

Examination of cranial nerves including fundus was normal. No papilloedema. Motor system (no hypotonia), sensory system and reflexes were all normal.

\section{Cerebellar Signs}

- No hypotonia.

- Intention tremors were absent.

- No ocular motor abnormalities noted including nystagmus.

- $\quad$ Finger nose test was positive on both sides with overshooting.

- Heel-Knee test was positive on both sides.

- Dysdiadochokinesis- present on both sides.

- $\quad$ Past-pointing test- positive both sides.

- $\quad$ Spiral drawing was not possible.

- Gait- Ataxic with tendency to swing on both sides.

- Patient was not able to walk in straight line.

\section{No Signs of Meningeal Irritation}

Other system examination including cardiovascular, respiratory and abdomen was normal. Her biochemical and serological tests including $\mathrm{CBC}$, blood sugar and kidney function tests were normal. Test for human immunodeficiency virus was negative.

'Financial or Other Competing Interest': None.

Submission 05-05-2018, Peer Review 01-06-2018,

Acceptance 08-06-2018, Published 18-06-2018.

Corresponding Author:

Dr. Dilip Pandurang Patil,

\#282/2/1, Budhwar Peth,

Near Krishna Naka, Karad-415110,

Dist-Satara, Maharashtra, India.

E-mail: patilhospitalkarad@gmail.com

DOI: $10.14260 /$ jemds $/ 2018 / 669$

\section{(c) $(1) \risingdotseq$}

With clinical examination she was suspected to have bilateral cerebellar lesion. To evaluate aetiological cause, she was investigated with Computerised Tomography of headbrain, which showed inferior descent of cerebellar tonsils (7$8 \mathrm{~mm}$ ) through foramen magnum into upper cervical canal. To confirm this finding and to look for syringomyelia Magnetic resonance imaging (MRI) brain and cervical spine was done which confirmed the descent of cerebellar tonsils (9.8 mm). On imaging studies supratentorial brain parenchyma, brain stem and ventricular system was normal. There was no evidence of spina bifida. With clinical features and imaging studies of brain and spine, patient was diagnosed to have Arnold-Chiari malformation (ACM Type I).

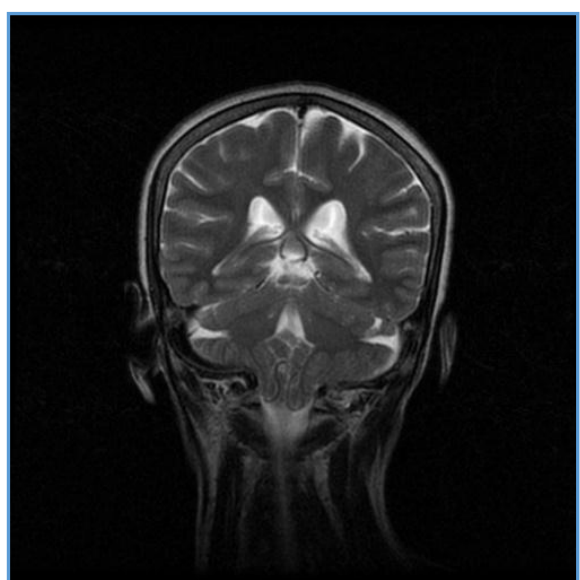

Image 1. T2W Coronal Image showing Tonsillar Herniation

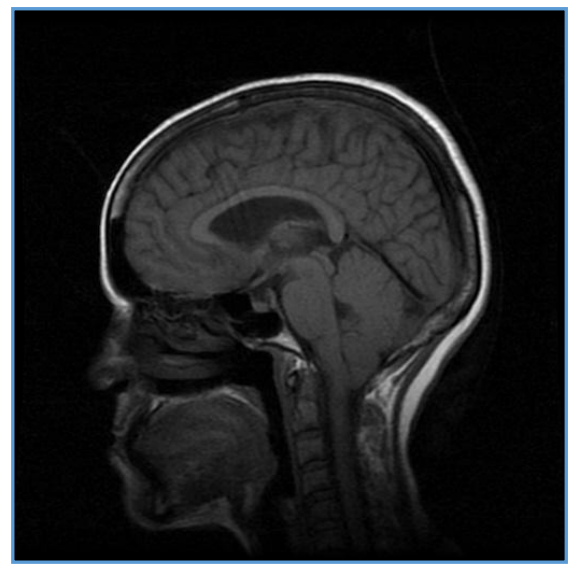

Image 2. T1W Sagittal Image showing Tonsillar Herniation

\section{DIFFERENTIAL DIAGNOSIS}

1. Cerebrovascular accident due to vascular involvement in posterior cerebral circulation.

2. Posterior cranial fossa tumour, eg. Cerebellopontine angle tumour.

3. Multiple sclerosis. 


\section{PATHOLOGICAL DISCUSSION}

The characteristic of ACM Type I is downward displacement of cerebellar tonsils through foramen magnum.(1) This congenital abnormality is often asymptomatic and detected incidentally in older children or adults.(2) Patient may present with occipital headache, lower cranial nerve palsy, sensorimotor abnormalities,(3) weakness and ataxia. As symptoms are not specific, it may cause delay in diagnosis.(4) In this case, patient presented with ataxia.

ACM Type I may become symptomatic in $3^{\text {rd }}$ or $4^{\text {th }}$ decade of life with clinical manifestation like headache, dizziness, tinnitus and ataxia. (This patient became symptomatic at the age of 40 years with ataxia). All these findings are nonspecific, so differential diagnosis of ACM Type 1 from other diseases is difficult. The diagnosis of ACM Type I is usually late; till it is correctly diagnosed it can be mistaken as multiple sclerosis, other degenerative conditions.(5)

\section{Diagnostic Criteria of Arnold-Chiari Malformation}

Criteria to diagnose Arnold-Chiari malformation (ACM) differ according to study. In normal adults more than $3 \mathrm{~mm}$ descent of cerebellar tonsils through foramen magnum is rare; descent more than $5 \mathrm{~mm}$ produces symptoms; so diagnostic criteria of ACM is descent of cerebellar tonsils more than $5 \mathrm{~mm}$ below foramen magnum. $(6,7)$

\section{Types of Arnold-Chiari Malformation}

Four various types of ACM have been described. The most common of these are Chiari types I and II.

\section{Type I}

Downward displacement of cerebellar tonsils through foramen magnum, is most often diagnosed in adulthood.

\section{Type II}

Commonly called Arnold-Chiari malformation characterised by descent of cerebellar tonsils, the inferior vermis and portion of cerebellar hemispheres into spinal canal along with elongation and displacement of brain stem and fourth ventricle. It is diagnosed in childhood and almost always associated with meningomyelocele and spina bifida.

\section{Type III}

Herniation of cerebellum and brain stem through foramen magnum into the spinal cord. This is rare, but most serious form and causes severe neuro deficit.

\section{Type IV}

This involves undeveloped cerebellum sometimes associated with exposed part of skull or spinal cord. This is a rare type. Type $\mathrm{I}$ is seen in adults becoming symptomatic in third decade of life (25 - 30 years).(8) Nearly $1 / 3^{\text {rd }}$ cases are asymptomatic. There is wide spectrum of clinical symptoms and signs with typical insidious onset and slow progression and significant neuro deficit in later stage.(9) Many times patient with ACM Type 1 presents with complex clinical features. These highly variable clinical manifestations are due to involvement of cerebellum, brain stem and upper cervical cord. Clinical manifestations are due to compression of neural structures at cranio-cervical junction or obstruction of CSF flow. ACM Type I malformation is accompanied by syringomyelia in $25-75 \%$ of cases. $(5,10,11)$ Our patient was not having syringomyelia. Location and length of syringomyelia decides patient's symptoms and clinical manifestations, so it varies from patient to patient. The commonest symptom is occipital headache which worsens with straining or coughing, but neck pain, ataxia, dysarthria, dysphagia, dissociated anaesthesia have been reported. Oculomotor nerve palsy produces visual disturbances.(1,12-14) Syncopal episodes are described, but are rare.(13) Raised intracranial pressure causing papilloedema due to tonsillar herniation is reported in $2 \%$ of cases.(15) This patient was not showing features of raised intracranial pressure or papilloedema.

Tip-Toe gait has been described by Gi Hoon Hwang et al,(16) our patient has ataxic gait.

To make differential diagnosis, clinical examination in depth with skeptical approach is needed. As our patient presented with ataxia, possibility of ACM Type I was thought of and evaluated accordingly with imaging study of brain and spine. Early and accurate diagnosis will help to refer these patients for surgical intervention before they develop further neurological complications.

\section{DISCUSSION OF MANAGEMENT}

Usually symptomatic patients with ACM Type I malformation are recommended surgical treatment with craniocervical decompression, but not for asymptomatic individuals. Symptoms are resolved after surgical intervention, but there are not many studies to prove this hypothesis.(17) As this patient was symptomatic, she is referred to neurosurgeon for surgical intervention.

\section{FINAL DIAGNOSIS}

Considering clinical history of ataxia, neurological examination and imaging study of brain with computerised tomography (CT scan) and magnetic resonance imaging (MRI) she was confirmed to have Arnold-Chiari malformation Type I.

\section{REFERENCES}

[1] Blagodatsky MD, Larionov SN, Alexandrov YA, et al. Surgical treatment of Chiari I malformation with or without syringomyelia. Acta Neurochir (Wien) 1999;141(9):963-8.

[2] Cartlidge NEF, Al Hakim M, Bradley WG. Disorders of bones, joints, ligaments, cartilage, and meninges. In: Bradley WG, Daroff RB, Fenichel GM, et al. eds. Neurology in Clinical practice. 2nd edn. Boston: Butterworth-Heinemann 1996: p. 1793-822.

[3] Prilipko O, Dehdashti AR, Zaim S, et al. Orthostatic intolerance and syncope associated with Chiari type I malformation. J Neurol Neurosurg \& Psychiatry 2005;76(7):1034-6.

[4] Chantigian RC, Koehn MA, Ramin KD, et al. Chiari I malformation in parturients. J Clin Anesth 2002;14(3):201-5.

[5] Gökalp HZ, Erongun U. Nöroşirürji Ders Kitabı. Ankara: Mars Matbaasi 1988.

[6] Aitken LA, Lindan CE, Sidney S, et al. Chiari type I malformation in a pediatric population. Pediatr Neurol 2009;40(6):449-54.

[7] Barkovich AJ, Wippold FJ, Sherman JL, et al. Significance of cerebellar tonsillar position on MR. AJNR Am J Neuroradiol 1986;7(5):795-9. 
[8] Steinbok P. Clinical features of Chiari I malformations. Child Nerv Syst 2004;20(5):329-31.

[9] Elster AD, Chen MY. Chiari I malformations: clinical and radiologic reappraisal. Radiology 1992;183(2):347-53.

[10] Yamanaka M, Uozumi T, Sakoda K, et al. MRI of Chiari malformations. Neurol Med Chir (Tokyo) 1990;30(4):246-50.

[11] Susman J, Jones C, Wheatley D. Arnold-Chiari malformation: a diagnostic challenge. Am Fam Physican 1989;39(3):207-11.

[12] Eisenstat DD, Bernstein M, Fleming JF, et al. Chiari malformation in adults: a review of 40 cases. Can J Neurol Sci 1986;13(3):221-8.
[13] Levy WJ, Mason L, Hahn JF. Chiari malformation presenting in adults: a surgical experience in 127 cases. Neurosurgery 1983;12(4):377-90.

[14] Nash J, Cheng JS, Meyer GA, et al. Chiari type I malformation: overview of diagnosis and treatment. Wisconsin Medical Journal 2002;101(8):35-40.

[15] Milhorat TH, Chou MW, Trinidad EM, et al. Chiari I malformation redefined: clinical and radiographic findings for 364 symptomatic patients. Neurosurgery 1999;44(5):1005-17.

[16] Hwang GH, Kim GC, Jeong HJ, et al. Arnold Chiari I malformation with Tip-Toe gait: a case report. Korean J Spine 2013;10(1):38-40.

[17] Garland EM, Robertson D. Chiari I malformation as a cause of orthostatic intolerance symptoms: a media myth? Am J Med 2001;111(7):546-52. 